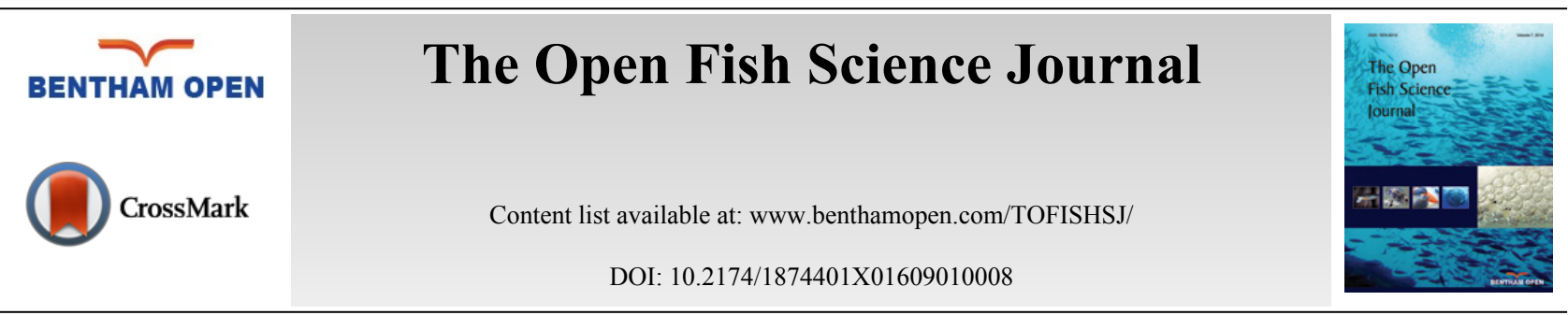

\title{
Do You Eat or Not? Predation Behaviour of European Catfish (Silurus glanis) Toward Live Bait on a Hook
}

\author{
Stéphanie Boulêtreau ${ }^{1,2}$, Pascal Verdeyroux ${ }^{3}$, Elise Lorthiois ${ }^{1,2}$, Frédéric Azémar ${ }^{1,2}$, Arthur Compin ${ }^{1,2}$ \\ and Frédéric Santoul ${ }^{1,2, *}$ \\ ${ }^{1}$ Université de Toulouse, UPS, INP, EcoLab (Laboratoire Ecologie Fonctionnelle et Environnement), 118, Route de \\ Narbonne, F-31062 Toulouse, France \\ ${ }^{2}$ CNRS, EcoLab, F-31062 Toulouse, France \\ ${ }^{3}$ EPIDOR (Etablissement Public Interdépartemental Dordogne), Place de la laïcité, 24250 Castelnaud-la-Chapelle, \\ France
}

\begin{abstract}
We filmed and analysed, in natural and field conditions, behaviours of large-bodied European catfish (Silurus glanis) individuals (body size ranging from 80 to $220 \mathrm{~cm}$ ) exposed to a hook baited with $20 \mathrm{~cm}$-long Carassius spp. Among a total of 95 individuals observed, $80 \%$ of the catfish clearly demonstrated interest in the bait but attacks were performed only $25 \%$ of the time and only $12.5 \%$ of fish were hooked. More than half of the individuals (55\%) were observed swimming toward the bait and then turning around or tasting it without performing any attacks. These observations showed that individual fish motivation and behaviour are important factors in determining whether European catfish are attracted to bait and eventually hooked.
\end{abstract}

Keywords: Bait, fishing, predation, river, top predator, video.

\section{INTRODUCTION}

Throughout history people have developed techniques to capture animals. Among these techniques the use of baits has been widespread. For instance, aerial baiting is an important rat eradication technique [1]. In aquatic ecosystems, the most important bait users remain anglers [2,3]. Despite great efforts to develop alternative, longline artificial baits [3], live baits continue to be largely used in recreational fishing and commercial longline fishing and to be preferred for successful catches (e.g., [4]).

Bait efficaciousness in catching fish depends on multiple interacting external and internal factors. Chemical and physical properties of the bait (e.g., size, shape, texture, and physical strength) directly control the likelihood that fish encounter, attack and, ingest the bait [5,6]. Environmental conditions such as photoperiod, light intensity, temperature, water current, and their temporal (diel, seasonal, annual) changes have also been demonstrated to affect fish feeding activity (e.g., [7 - 9]). Internal factors driving food-searching motivation are also known to affect feeding behaviour [10]. Factors that elicit fish-food search detection and location have been well described [3], however, fish predation behaviour and its response to bait in natural conditions remain poorly known, mainly due to difficulties observing fish in the field.

In the marine environment, video techniques based on underwater cameras are increasingly used for their nondestructiveness, compared with capture techniques. Anchored baits monitored by remote underwater cameras is a useful method to estimate fish diversity and behaviour since it usually does not introduce changes in behaviour [11 - 13]. These techniques have been underutilized in the freshwater environment, and could provide relevant information for

\footnotetext{
* Address correspondence to this author at the Université de Toulouse, UPS, INP, EcoLab (Laboratoire Ecologie Fonctionnelle et Environnement), 118, Route de Narbonne, F-31062 Toulouse, France; Tel: +33 (0)561556575; E-mail: frederic.santoul@univ-tlse3.fr
} 
investigating fish assemblages and behaviours, especially in large river systems.

The European catfish is very popular with anglers because of the large body size -it is the largest European freshwater fish [14]. The European catfish is also a relevant model to perform observations in natural conditions. Here, we describe the behaviour of European catfish and measure their responses to a baited using video cameras and hooked live bait.

\section{METHODS}

Thirteen fishing trials (1.5-hour long) were conducted in the Dordogne River (southwest France, coordinates $44^{\circ} 85^{\prime} 56^{\prime}$ N, $0^{\circ} 56^{\prime} 55^{\prime \prime} \mathrm{E}$ ) from 15 August to 25 September2013 in the late morning (between 11 am and 3 pm) by the same experienced angler (PV). A Fishing trial consisted of in longline fishing with a boat along river transects using a single hook and live bait. The Dordogne River is public domain with free access for anglers with a fishing license.

One $20 \mathrm{~cm}$-long cyprinid (Carassius spp.) was used as live bait. Live baits are traditionally used in recreational fishing, commercial longline fishing, and in some experimental studies (e.g., $[15,16])$. An underwater camera (Bullet Camera - Sports HD mini DV 30m 1280*720p) was fixed on the bait line, $1.2 \mathrm{~m}$ up from the bait and filmed the immediate surrounding environment around the bait $(<3 \mathrm{~m})$. Fishing trials were conducted when permitted by water visibility (between 1 to $1.5 \mathrm{~m}$ ) and, during a short time (annual and diel) period to prevent variability from environmental changes and changes in feeding patterns.

Water temperature $\left(25.7{ }^{\circ} \mathrm{C} \pm 3.2 \mathrm{SD}\right)$ and current (mean discharge $\left.108 \mathrm{~m}^{3} \mathrm{~s}^{-1} \pm 17 \mathrm{SD}\right)$ were stable during trial periods. Observations were performed in a large stretch of the river (mean length $=30 \mathrm{~km}$, mean width $=80 \mathrm{~m}$ ) to decrease the probability of encountering the same individual from another trial. Individual natural marks (e.g., pectoral fin injury) were used to discriminate among individuals and avoid pseudo replication during the trials. In total 103 European catfish individuals were observed on the $17 \mathrm{~h}$ of video footages. Footages that did not accurately describe catfish behaviour or allow an estimate of catfish body size were not analysed. In addition, catfish individuals with body size below $80 \mathrm{~cm}$ were excluded from the analysis to ensure that every observed individual was able to ingest the bait [17].

Five fish behaviours were defined from the video analysis and used to characterise catfish reactions in front of the bait (see movie S1):

- Ignore: the catfish individual identified the bait but ignored it and swam away.

- Approach: the individual moved toward the bait while looking at it, then turned around.

- Taste: the individual moved toward the bait and touched it with barbels or head.

- Spit: the individual ingested the bait but spit it out before swimming away.

- Hooked: the individual ingested the bait and was hooked.

We compared body size between individuals that exhibited different fish behaviours using non-parametric tests (Kruskal-Wallis test and Mann-Whitney test). The direction from which the bait was tasted or ingested (front, behind, or sides) was determined for each catfish individual. We also measured and compared the time between catfish appearance in the field of the camera and catfish action, i.e., tasting the bait (first occurrence) or ingesting the bait. Statistical analyses were conducted using R software.

\section{RESULTS}

The behaviour of 95 catfish individuals and their reaction to live bait in the river were analysed. Their body size averaged $147 \mathrm{~cm}$, ranging from 80 to $220 \mathrm{~cm}$, and sizes were distributed as follows: 11 individuals in 80-100; 34 individuals in 100-150; 43 individuals in 150-200; 7 individuals in 200-220.

Seventy-six individuals ( $80 \%$ ) clearly demonstrated interest toward the bait, with 19 remaining individuals ignoring it Fig. (1). Among these individuals, 52 approached $(\mathrm{n}=15$, i.e. $16 \%)$ or tasted the bait $(\mathrm{n}=37$, i.e. $39 \%)$ before swimming away (Fig. 1). The remaining 24 individuals (25\%) that bit the bait, rejected it and swam away, while the other half ingested the bait. Among these 12 hooked fish, the angler caught 6 . These results also confirm that European catfish is not only a nocturnal predator but can be also active across diurnal periods in rivers, see also [18]. 


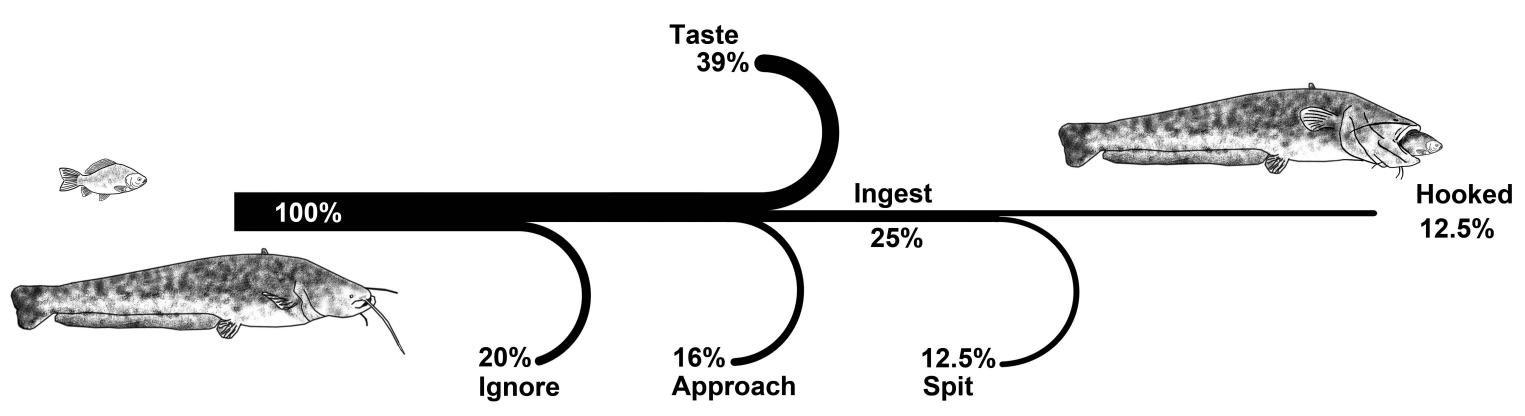

Fig. (1). Types of European catfish behaviour toward bait. Fish were exposed to live fish in the Dordogne River, France from August to September 2013.

Individual body size significantly differed between behaviour types (Kruskal-Wallis test, $\mathrm{p}<0.01$ ) with hooked individuals larger than individuals exhibiting Ignore behaviour (Mann-Whitney test, $\mathrm{p}<0.01$ ), Approach behaviour ( $\mathrm{p}$ $<0.01)$, Taste behaviour $(\mathrm{p}<0.01)$ and Spit behaviour $(\mathrm{p}<0.01)$ (Fig. 2). Other behaviour comparisons in body size were not significant.

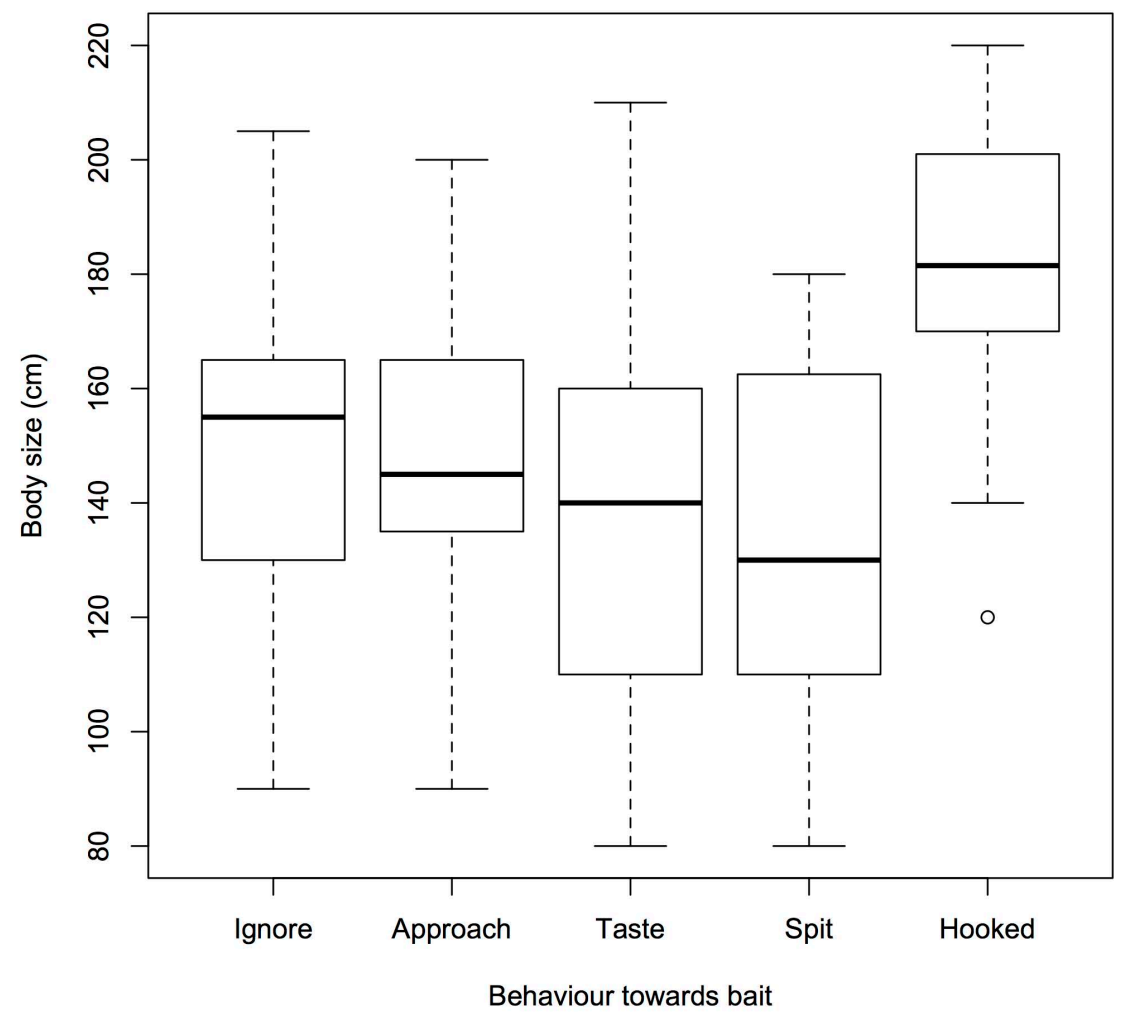

Fig. (2). Body size of European catfish individuals for each identified type of behaviour toward bait. Fish were exposed to live fish in the Dordogne River, France from August to September 2013.

Tasting the bait was the most frequently observed behaviour and was decomposed into two patterns: catfish individuals tasted the bait with flexible cartilaginous barbs (31\%), whereas other $(69 \%)$ tasted the bait with upper jaw and fleshy lips exhibiting a typical slow-sliding movement on the bait (Fig. 3). 


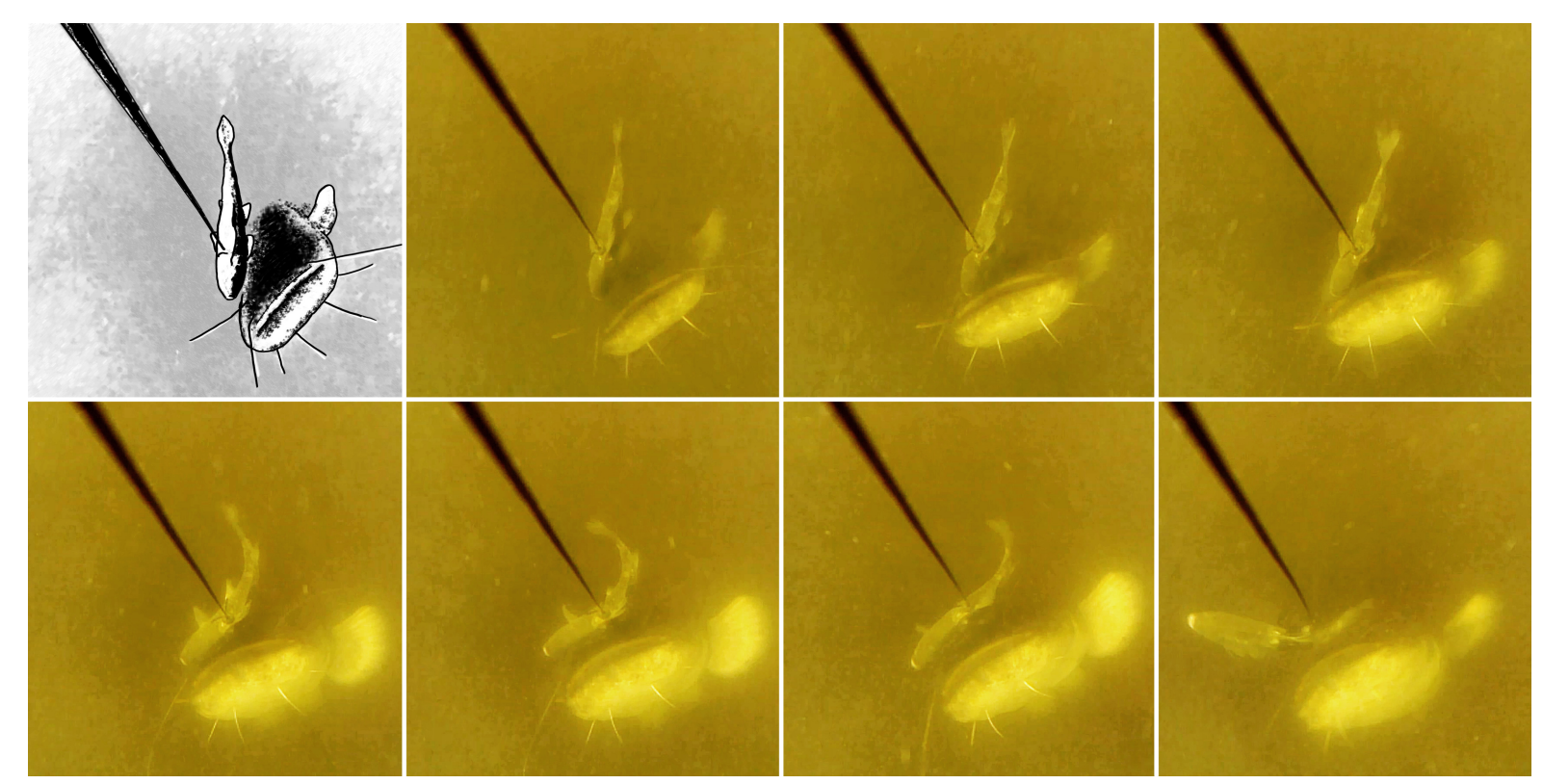

Fig. (3). Image sequence detailing Taste behaviour. The European catfish tastes with upper jaw and fleshy lips with a typical slow sliding movement on the bait. The sequence lasts for a total of 3 seconds. Fish were exposed to live fish in the Dordogne River, France from August to September 2013.

Individuals that ingested the bait had never gone toward it from the front whereas $31 \%$ of the individuals that tasted it had gone from the front (Fig. 4). Around $60 \%$ of the individuals that tasted or ingest the bait approached it from the side. Thirty-seven $\%$ of hooked individuals attacked the bait from behind; while $10 \%$ of catfish tasted the bait from behind.

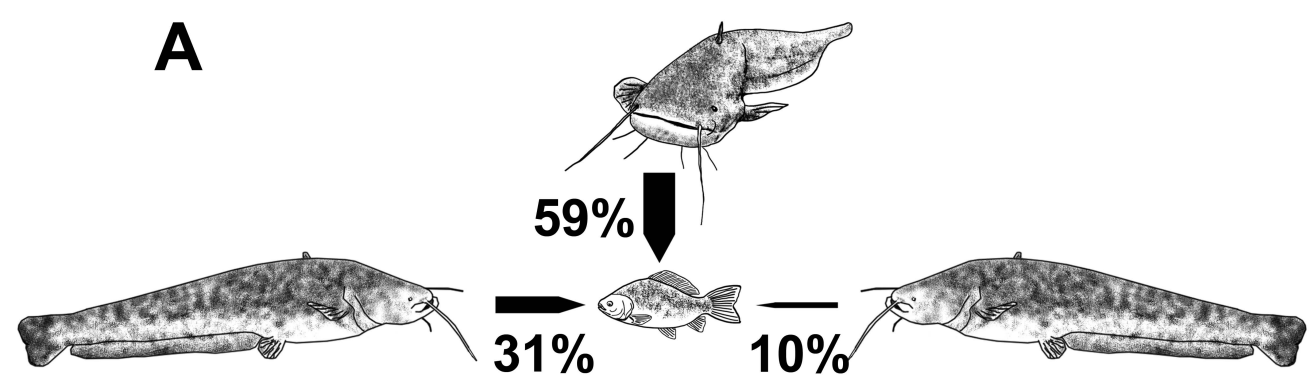

\section{TASTE}

B

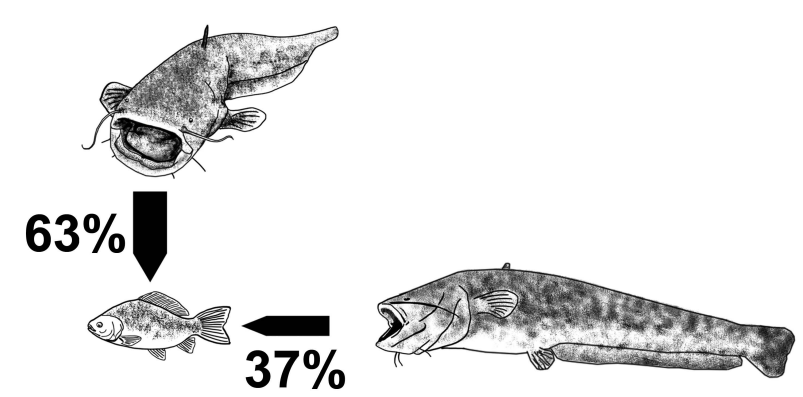

\section{INGEST}

Fig. (4). Directions from which the European catfish tasted (A) or ingested (B) the bait (front, sides, behind). Fish were exposed to live fish in the Dordogne River, France from August to September 2013. 
Time between catfish appearance on the footage and catfish action was shorter for individuals that ingested the bait $(1.7 \mathrm{~s} \pm 0.8 \mathrm{~s} \mathrm{SD})$ than for individuals that tasted it $(4 \mathrm{~s} \pm 1.6 \mathrm{~s} \mathrm{SD}$; Mann-Whitney test, $\mathrm{p}<0.001)$.

\section{DISCUSSION}

Use of baits is a widespread technique used by anglers and fishermen, but fish behaviour toward bait remains unexplored. We documented the feeding motivation of European catfish toward a live baited hook, by exposing the same type of bait in similar natural environmental conditions to catfish individuals and describing their behaviour toward the bait once they located the prey. Diel dualism in the activity of European catfish occurs in the wild and diel activity and energy consumption differs across the seasons [18]. In a Czech river, European catfish were active across the whole $24 \mathrm{~h}$ in summer [18]. Some individuals use energy only during the day and others during the night [19, 20].

Our study show 95 European catfish detected and located live bait. Bait attractiveness to catfish is likely due to bait type i.e., moving live bait. Indeed, detection of food is mainly based on taste, with taste organs in the oral cavity and elsewhere on the body surface [21]. In rivers, current promotes scent dispersion of olfactory cues. In laboratory tests, juveniles of European catfish were shown to use scent wakes that trailed swimming guppies (Poecilia reticulata) to detect and track them in complete darkness [22]. In addition, catfish find moving prey easier to detect and locate [22]. Finally, chemical traces produced by a stressed prey fish are known to strongly stimulate predator behaviour and trigger food searches [23].

Though 76 catfish individuals demonstrated a clear interest in live bait, the experienced angler only caught 6 catfish, and failed in capturing 6 others that were hooked. The low of hooked individuals demonstrated that attracting fish does not mean catching fish, suggesting that fish motivation and behaviour are determinants to consider among factors that encourage catfish to ingest bait. Among the 76 individuals which demonstrated interest toward live bait, 52 'curious' catfish individuals, but suspicious, approached the bait or even tasted it without biting it, using their fleshy lips and barbels to explore it. The others exhibited rapid attack behaviour, but in $50 \%$ of observations, catfish spit the baited hook after ingesting it, probably because of their high gustatory and mechanosensory systems [24]. Catfish individuals exhibiting this attack behaviour displayed a large range of body sizes $(80-220 \mathrm{~cm})$. Though bait size was unlikely to influence body size of catfish individuals approaching, tasting or ingesting the bait, individuals spitting bait were smaller than hooked individuals. Having a smaller mouth may increase the probability of coming into contact with the hook, thus triggering an aversive avoidance reaction from the fish.

Catfish that ingested the prey had never initiated their attack from the front of the prey but approached, from the sides $(63 \%)$ or from behind (37\%), probably to minimize the risk of being seen. However, $31 \%$ of the individuals that tasted the bait had initiated their approach from the front, may be because of less motivation to catch prey. Attacking prey from the sides is an optimal strategy for a predator, because this direction increases available prey surface and optimizes the chance of reaching the prey before escape $[25,26]$. Most juvenile European catfish attacks were initiated from behind (46\%) [22].

A learning process associated with angling pressure could explain catfish behaviour toward bait, since previous angling experiences have been reported in the literature to affect catch rate. Angling pressure was shown to cause hook avoidance in Salmo trutta [27] and in Gadus morhua [28]. However, catchability of pike Esox lucius remained unaffected by previous captures with live baits [29]. Caught and released wild white-spotted charr (Salvelinus leucomaenis) were more likely to be caught than fish no caught before [30]. In their study on catch returns of European catfish, [31] demonstrated that some fish were more catchable than others, with some individuals caught numerous time and other never caught, suggesting that hook avoidance would not be a feature of that species.

The present observations showed that fish individual behaviour and motivation are important factors in determining European catfish catch success period. Further experiments are needed to test how individual fish behaviour, experience, and life history may affect fish feeding behaviour.

\section{CONFLICT OF INTEREST}

The authors confirm that this article content has no conflict of interest.

\section{ACKNOWLEDGEMENTS}

The authors would like to thanks N. Guillerault and Dr. David J. Jude for their useful comments in the previous version of this manuscript. 


\section{REFERENCES}

[1] Samaniego-Herrera A, Anderson DP, Parkes JP, Aguirre-Munoz A. Rapid assessment of rat eradication after aerial baiting. J Appl Ecol 2013; 50: $1415-21$.

[http://dx.doi.org/10.1111/1365-2664.12147]

[2] Locker A. The social history of coarse angling in England AD 1750-1950. Anthropozoologica 2014; 49(1): 99-107. [http://dx.doi.org/10.5252/az2014n1a07]

[3] Løkkeborg S, Siikavuopio SI, Humborstad O, Utne-Palm A, Ferter K. Towards more efficient longline fisheries: fish feeding behaviour, bait characteristics and development of alternative baits. Rev Fish Biol Fish 2014; 24: 985-1003. [http://dx.doi.org/10.1007/s11160-014-9360-z]

[4] Litvak MK, Mandrak NE. Ecology of freshwater baitfish use in Canada and the United States. Fisheries (Bethesda, Md) 1993 ; $18(12)$ : 6-13. [http://dx.doi.org/10.1577/1548-8446(1993)018<0006:EOFBUI >2.0.CO;2]

[5] Atema J. Chemical senses, chemical signals and feeding behavior in fishes. In: Bardach JE, Magnuson JJ, May RC, Reinhart JM, Eds. Fish behavior and its use in the capture and culture of fishes. Manila: International Centre for Living Aquatic Resources Management 1980; pp. $57-101$

[6] Bjordal A, Løkkeborg S. Longlining fishing new books. UK: Cambridge University Press 1996.

[7] Jørgensen EH, Jobling M. Patterns of food intake in Arctic charr, Salvelinus alpinus, monitored by radiography. Aquaculture 1989; 81: 155-60.

[http://dx.doi.org/10.1016/0044-8486(89)90241-X]

[8] Løkkeborg S, Bjordal A, Ferno A. Responses of cod (Gadus morhua) and haddock (Melanogrammus aeglefinus) to baited hooks in the natural environment. Can J Fish Aquat Sci 1989; 46: 1478-83. [http://dx.doi.org/10.1139/f89-189]

[9] Fraser NH, Metcalfe NB, Thorp JE. Temperature-dependent switch between diurnal and nocturnal foraging in salmon. Proc R Soc Lond 1993; 252: $135-9$.

[http://dx.doi.org/10.1098/rspb.1993.0057]

[10] Løkkeborg S, Bjordal A. Size-selective effects of increasing bait size by using an inedible body on longline hooks. Fish Res 1995; 24 : 273-9. [http://dx.doi.org/10.1016/0165-7836(95)00393-6]

[11] Langlois T, Chabanet P, Pelletier D, Harvey ES. Baited underwater video for assessing reef fish populations in marine reserves. SPC Fisheries Newsletter 2006; pp. 53-7.

[12] Dorman SR, Harvey ES, Newman SJ. Bait effects in sampling coral reef fish assemblages with stereo-BRUVs. PLoS One 2012; 7(7): e41538. [http://dx.doi.org/10.1371/journal.pone.0041538] [PMID: 22848522]

[13] Mallet D, Wantiez L, Lemouellic S, Vigliola L, Pelletier D. Complementarity of rotating video and underwater visual census for assessing species richness, frequency and density of reef fish on coral reef slopes. PLoS One 2014; 9(1): e84344. [http://dx.doi.org/10.1371/journal.pone.0084344] [PMID: 24392126]

[14] Stone R. Aquatic ecology. The last of the leviathans. Science 2007; 316(5832): 1684-8. [http://dx.doi.org/10.1126/science.316.5832.1684] [PMID: 17588909]

[15] Clapp DF, Clark RD. Hooking mortality of smallmouth bass caught on live minnows and artificial spinners. N Am J Fish Manage 1989; 9(1): $81-5$. [http://dx.doi.org/10.1577/1548-8675(1989)009<0081:HMOSBC $>2.3 . \mathrm{CO} ; 2]$

[16] Margenau TL, Petchenik JB. Social aspects of muskellunge management in Wisconsin. N Am J Fish Manage 2004; $24: 82-93$. [http://dx.doi.org/10.1577/M02-045]

[17] Wysujack K, Mehner T. Can feeding of European catfish prevent cyprinids from reaching a size refuge? Ecol Freshwat Fish 2005; $14: 87-95$. [http://dx.doi.org/10.1111/j.1600-0633.2004.00081.x]

[18] Slavík O, Horký P, Bartoš L, Kolářová J, Randák T. Diurnal and seasonal behaviour of adult and juvenile European catfish as determined by radio-telemetry in the River Berounka, Czech Republic. J Fish Biol 2007; 71: 104-14. [http://dx.doi.org/10.1111/j.1095-8649.2007.01471.x]

[19] Slavík O, Horký P. When fish meet fish as determined by biotelemetry. Ecol Freshwat Fish 2009; 18: 501-6. [http://dx.doi.org/10.1111/j.1600-0633.2009.00370.x]

[20] Slavík O, Pešta M, Horký P. Effect of grading on energy consumption in European catfish Silurus glanis. Aquaculture 2011; $313: 73-8$. [http://dx.doi.org/10.1016/j.aquaculture.2011.01.002]

[21] Copp GH, Britton JR, Cucherousset J, et al. Voracious invader or benign feline? A review of the environmental biology of European catfish Silurus glanis in its native and introduced ranges. Fish Fish 2009; 10: 252-82. [http://dx.doi.org/10.1111/j.1467-2979.2008.00321.x]

[22] Pohlmann K, Grasso FW, Breithaupt T. Tracking wakes: the nocturnal predatory strategy of piscivorous catfish. Proc Natl Acad Sci USA 2001; 98(13): 7371-4.

[http://dx.doi.org/10.1073/pnas.121026298] [PMID: 11390962] 
[23] Malyukina GA, Martem'yanov VI. An electrocardiographic study of chemical sensitivity in some freshwater fishes. J Ichthyol 1981; 21: 77-84.

[24] Kasumyan AO, Døving KB. Taste preferences in fishes. Fish Fish 2003; 4: 289-347. [http://dx.doi.org/10.1046/j.1467-2979.2003.00121.x]

[25] Webb PW, Skadsen JM. Strike tactics of Esox. Can J Zool 1980; 58(8): 1462-9. [http://dx.doi.org/10.1139/z80-201] [PMID: 7427833]

[26] Domenici P. The scaling of locomotor performance in predator-prey encounters: from fish to killer whales. Comp Biochem Physiol A Mol Integr Physiol 2001; 131(1): 169-82. [http://dx.doi.org/10.1016/S1095-6433(01)00465-2] [PMID: 11733175]

[27] Young RG, Hayes JW. Angling pressure and trout catchability: behavioral observations of Brown trout in two New Zealand backcountry rivers. N Am J Fish Manage 2004; 24: 1203-13. [http://dx.doi.org/10.1577/M03-177.1]

[28] Fernö A, Huse I. The effect of experience on the behaviour of cod (Gadus morhua L.) towards a baited hook. Fish Res 1983; 2: 19-28. [http://dx.doi.org/10.1016/0165-7836(83)90100-5]

[29] Beukema JJ. Acquired hook-avoidance in the pike Esox lucius L. fished with artificial and natural baits. J Fish Biol 1970; 2: 155-60. [http://dx.doi.org/10.1111/j.1095-8649.1970.tb03268.x]

[30] Morita K, Tsuboi J. Selectivity effects on wild white-spotted charr (Salvelinus leucomaenis) during a catch and release fishery. Fish Res 2004; 69: 229-38.

[http://dx.doi.org/10.1016/j.fishres.2004.04.009]

[31] Britton JR, Pegg J, Sedgwick R, Page R. Investigating the catch returns and growth rate of wels catfish, Silurus glanis, using mark-recapture. Fish Manag Ecol 2007; 14: 263-8. [http://dx.doi.org/10.1111/j.1365-2400.2007.00554.x]

Received: August 31, 2015 Revised: November 13, 2015 Accepted: November 17, 2015

(C) Boulêtreau et al. Licensee Bentham Open.

This is an open access article licensed under the terms of the Creative Commons Attribution-Non-Commercial 4.0 International Public License (CC BY-NC 4.0) (https://creativecommons.org/licenses/by-nc/4.0/legalcode), which permits unrestricted, non-commercial use, distribution and reproduction in any medium, provided the work is properly cited. 